\title{
Influence of polyurethane adhesives on tensile and compressive properties of ground rubber composites
}

\author{
Antanas Strakšys ${ }^{1}$, \\ Ignas Valsiūnas ${ }^{1}$, \\ Giedrius Stalnionis ${ }^{1}$, \\ Olegas Eicher-Lorka ${ }^{1}$, \\ Zenonas Kuodis ${ }^{1}$, \\ Dalia Bražinskiené1, \\ Artūras Jukna², \\ Svajus Asadauskas ${ }^{1 \star}$ \\ ${ }^{1}$ Center for Physical Sciences \\ and Technology (FTMC), \\ Sauletekio St. 3, \\ 10257 Vilnius, Lithuania \\ ${ }^{2}$ Joint Stock Company \\ UAB Gumos Technologijos, \\ Biržišku St. 19, \\ 11111 Vilnius, Lithuania
}

\begin{abstract}
Rubber from End-of-Life Tires (ELT) is often used as secondary raw material for composites. Polyurethane adhesives are widely employed in such formulations, since they bind to rubber particles effectively. In this study Ground Tire Rubber of passenger car ELT and truck tire tread buffings were used as feedstock. Toluene diisocyanate was used as a hardener for polyether-based prepolymer resin. Hardener amounts, curing durations and temperatures were varied to produce composite sheets. Scanning electron microscopy showed differences in the type of voids within the sheet and suggested that the amount of adhesive, surface wetting and curing regime could affect the composite structure significantly. Tensile and compressive properties of the composites were more dependent on the adhesive amount than curing temperature variation below $60^{\circ} \mathrm{C}$. Better understanding how to control physical and mechanical properties of such composites will significantly contribute to value-added utilization of ELT as well as environmental and societal benefits.
\end{abstract}

Keywords: rubber, recycling, adhesives, composites

\section{INTRODUCTION}

Waste rubber waste from End-of-Life Tires (ELT) presents increasingly alarming environmental, economic, transport, industrial and other issues nearly in every country. Globally, over 3 billion tires are produced annually and ELT utilization trends can be very different [1]. A significant portion of ELT is used as fuel in cement kilns, but some rubber is often reclaimed as well and reused for various purposes. Usually rubber recovery starts with mechanical grinding of ELT to

*Corresponding author. Email: asadauskas@chi.lt separate Ground Tire Rubber (GTR). These crumbs can be further processed to reduce their size, activate their surface, devulcanize comparatively weak sulfur-sulfur cross-links in the rubber matrix [2]. All these processes are technologically intensive and energy demanding. Nevertheless, rubber, recovered from ELT, finds many reuse applications, such as glued composites, in particular mats, tiles, dampeners, shingles, etc.

Polyurethane (PUR) adhesives are among the most widely used gluing materials for rubber composites. They are favoured for production of rigid or flexible composites, because PUR itself is a very popular raw material for polymeric foams. For example, 70 to $90 \mathrm{wt} . \%$ of the PUR matrix 
were reported to effectively incorporate 10 to $30 \mathrm{wt} . \%$ GTR and mechanochemically reclaimed rubber into elastic foams [3]. Polymethylene polyaryl isocyanate (PAPI, PM200 ) with the NCO content of $31 \%$, tertiary amine (Dabco $33-\mathrm{LV})$ and polyether-based (OH value: $240 \mathrm{mgKOH} / \mathrm{g}$ ) TMN700 were utilized for that formulation [3].

Foams can also be produced with much more GTR and lower PUR contents, however, their flexibility is poorer. Good compressive properties of rubber foam with polyether polyol were reported at 200 parts GTR, 3 parts water, 0.6 part Tegostab B8225, 0.086 part 1,4-diazabicyclo[2,2,2] octane catalyst, 0.25 part dibutyltin dilaurate catalyst and isocyanate index of $105 \%$ [ [4]. This translates into 30 to 35 wt. $\%$ of PU adhesive contents.

Several research teams tried to combine low density, high flexibility and good mechanical strength with high rubber contents. Formulations with diphenyl methane 4,4-diisocyanate at $25-28 \mathrm{wt} . \%$, polybutadiene at $45-55 \mathrm{wt} . \%$, polyether at $15-20 \mathrm{wt} . \%$, plasticizer at $10-15 \mathrm{wt} . \%$ and additives at 2-4 wt.\% were reported as very effective. The best tensile strength was recorded at 10-100 phr, with the best elongation at 10-20 phr of binder to the total rubber compound of $211 \mathrm{phr}$. This translates into the PUR adhesive contents at $5-10 \mathrm{wt} . \%$. The best size for rubber particles was established for the interval from 0.7 to $2.5 \mathrm{~mm}$ [5].

Another report found Chemolan M (i.e. toluene 2,4-diisocyanate at $80 \mathrm{wt} \%$ and toluene 2,6-diisocyanate at $20 \mathrm{wt} . \%$ prepolymer with poly-oxypropylene of $2000 \mathrm{~g} / \mathrm{mol}$ ) to bind effectively with GTR. The optimum hardness and elasticity was achieved with the Chemolan $\mathrm{M}$ treat rate interval from 10 to $30 \mathrm{wt} . \%$ [6]. Similar amounts of PUR adhesives, up to $23 \mathrm{wt} . \%$, were reported during investigations of water absorption into GTR composites [ [].

Among the most critical properties for the vast majority of rubber-PU composites are tensile and compressive properties. The reviewed literature shows that several key aspects dictate these properties:

- individual tensile and compressive properties of rubber and cured PU adhesives;

- rubber particle size and their surface area;

- ability of adhesives to wet and adsorb to the rubber surface;

- ability of adhesives to penetrate and swell the rubber matrix [8];

- adhesive curing parameters (temperature, duration, humidity, etc.);

- possibly other aspects.

Adhesive adsorption onto the rubber particles and surface wetting might be particularly important industrially. If wetting is poor or spreading is slow, it might take long time until the adhesive coats a sufficient surface area of the rubber particles to assure satisfactory bonding. Since the adhesive itself might be congealing during the process, it is important to have rapid spreading and excellent wetting properties. In this study, a typical polyether-based
PUR adhesive was used to form composite sheets with two different types of rubber from ELT. The experimental scope was limited to the composite formulation and testing in order to measure tensile strength, elongation, compressive strength, compression and Young's modulus (both tensile and compressive). Particular attention was devoted to the formulation aspects and curing temperatures, trying to minimize the impact of humidity and other side factors. Some composite sheets were inspected using microscopy to suggest possible mechanisms of their formation.

\section{EXPERIMENTAL}

\section{Materials}

Two different types of ELT rubber were used for composite preparation. The Ground Tire Rubber (GTR) sample was obtained from UAB Metaloidas (Lithuania), reportedly manufactured from passenger car tires. A granulometric fraction of 2-3 mm was predominant. Truck tire tread buffings were supplied by Gumos Technologijos (Lithuania), reportedly being obtained mostly from tires, which were originally produced by manufacturers of the European Tire and Rubber Manufacturers Association (ETRMA). Each shipment was carefully mixed by intensive shaking and agitation to assure a homogeneous distribution of rubber particles within the whole volume. The Hardener Desmodur $^{\text {re }}$ T80 (Covestro, Germany) and resin for PUR adhesive preparation were also supplied by Gumos Technologijos. The FTIR spectra of the TDI hardener showed a major absorption band at $2238 \mathrm{~cm}^{-1}$, with other properties being typical of two isomeric forms 2,4-toluene diisocyanate and 2,6-toluene diisocyanate at 4:1 ratio. The resin represented a viscous opaque pasty liquid. Sodium hydroxide, hydrogen chloride, dibutylamine, pyridine and phthalic acid anhydride were purchased from Sigma-Aldrich (via UAB Labochema, Lithuania). Acetone (technical grade) and other solvents were purchased from UAB Eksparas (Lithuania) and used to clean equipment and glassware.

\section{Spectral analysis}

Raman spectra were recorded using an Echelle type spectrometer RamanFlex 400 (PerkinElmer, Inc.) equipped with a thermoelectrically cooled $\left(-50^{\circ} \mathrm{C}\right) \mathrm{CCD}$ camera and a fiber-optic cable for excitation and collection of the Raman spectra. The 785-nm beam of the diode laser was used as the excitation source. The $180^{\circ}$ scattering geometry was employed. The laser power at the sample was restricted to $50 \mathrm{~mW}$ and the beam was focused to a $200 \mu \mathrm{m}$ diameter spot on the sample. The integration time was $10 \mathrm{~s}$. Each spectrum was recorded by accumulation of 60 scans, yielding total 600 s time accumulation. The Raman frequencies were calibrated using the polystyrene standard (ASTM E 1840) spectrum. Intensities were calibrated by the NIST intensity standard (SRM 2241). 
Infrared spectra were recorded on ZnSe in the absorbance mode on an ALPHA FTIR spectrometer (Bruker, Inc., Germany) equipped with a room-temperature detector DLATGS. The spectral resolution was set at $4 \mathrm{~cm}^{-1}$. The spectra were acquired from 40 scans.

Nuclear magnetic resonance spectra were recorded in deuterated dimethyl sulfoxide - $\left(\mathrm{CD}_{3}\right)_{2} \mathrm{SO}$ on a Varian Unity Inova NMR spectrometer $\left({ }^{1} \mathrm{H}\right.$ at $\left.300 \mathrm{MHz}\right)$ using a solvent signal as an internal standard.

\section{Preparation of PUR adhesive and composite sheets}

Plastic Petri dishes of $90 \mathrm{~mm}$ ID and $10 \mathrm{~mm}$ deep were used to formulate adhesives and composite sheets. The PUR adhesive was prepared by vigorously mixing the TDI hardener and resin at 15:85 ratio in a Petri dish using a spatula and then leaving it stagnant to cure in air atmosphere for $4 \mathrm{~h}$ at specified temperatures (usually $60^{\circ} \mathrm{C}$ ) by placing into a drying oven. The composite sheets were prepared by mixing the resin with rubber particles using the spatula, then adding the TDI hardener and vigorously mixing again. At the end of mixing the contents of the Petri dish were tapped on the surface using the spatula with sufficient force to obtain compact mass. Then the Petri dish was placed into the oven for curing, after which the composite sheets were kept stagnant for at least $16 \mathrm{~h}$ at ambient conditions $\left(18\right.$ to $23^{\circ} \mathrm{C}$, humidity from 15 to $\left.40 \% \mathrm{RH}\right)$. Afterwards the plastic Petri dish was removed to release the cured composite sheet, which was used for further testing.

In order to record data on the PUR adhesive itself, the same procedure was used by omitting the addition of rubber particles. Also, in these experiments the ratio of the TDI hardener and resin was not kept at 15:85, but varied in the interval from 5:95 to 40:60.

\section{Density measurements}

The cured composite sheet was cut using a sharp razor to produce a cube of $10 \times 10 \times 10 \mathrm{~mm}$ in dimensions. The length, width and height of the cube was accurately measured to calculate the total volume. The cube was weighed using the precision balance Kern ALT-100. All the measurements were performed at room temperature of 18 to $22^{\circ} \mathrm{C}$. The density was calculated as $\mathrm{g} / \mathrm{cm}^{3}$.

\section{Tensile and compressive properties}

The tensile tests were performed on the Mecmesin Emperor ${ }^{\mathrm{m}}$ Force machine, using the extension velocity of $50 \mathrm{~mm} / \mathrm{min}$ at room temperature $\left(20^{\circ} \mathrm{C}\right)$. The samples were cut by using a sharp razor into specimens $10 \mathrm{~mm}$ wide and $\sim 80 \mathrm{~mm}$ long. The specimens were clamped at $8 \mathrm{~mm}$ from each end. The test lasted until sample breaking. The tensile strength at break $(\sigma \mathrm{R})$, Young's modulus (E) and elongation at break $(\varepsilon R)$ were measured [9]. In this report the terms tensile strength $\sigma_{R}$ (in MPa) and elongation $X_{R}$, (in \%) are often used by omitting the indication that they have been measured at break. Such indication is not needed, since both parameters were measured at break.
The compression tests were performed on the Mecmesin Emperor $^{\mathrm{rt}}$ Force machine, using the compression velocity of $2 \mathrm{~mm} / \mathrm{min}$ at room temperature $\left(20^{\circ} \mathrm{C}\right)$. The samples were cut by using the sharp razor into the specimens $10 \mathrm{~mm}$ wide and $10 \mathrm{~mm}$ long. Compressive strength at yield $\left(\sigma_{\mathrm{S}}^{*}\right)$, compressive strength at break $\left(\sigma_{\mathrm{R}}^{*}\right)$ and compressive modulus $\left(E^{\star}\right)$ were measured.

\section{Visual evaluation and microscopy}

The samples of rubber particle batches and the produced composite sheets were inspected visually before mechanical testing. The most important items were photographed with a conventional camera at 5 megapixel or higher resolution. Images from scanning electron microscopy (SEM) were acquired with a Helios NanoLab 650 Scanning Electron Microscope (Thermo Fisher Scientific - FEI, Netherlands). Specimens for SEM were prepared by cutting off a thin slice (less than $1 \mathrm{~mm}$ thick) of the composite sheet with a sharp razor. All slices were sputtered with a conductive layer of gold at approx. $5 \mathrm{~nm}$ thickness using a Quorum Q150T ES device (Judges Scientific Plc, UK) before their SEM analysis.

\section{RESULTS AND DISCUSSION}

Composite properties can be strongly affected by the properties of individual components, in this case rubber particles and PU adhesive on their own. When mixing the particles and adhesive, the ability of the adhesive to wet the particle surface and penetrate into any openings is also crucial. Finally, any bonding between the particles and adhesive is of great importance to tensile and compressive properties as well. Therefore, the research results are subdivided into separated sub-chapters according to the above aspects.

\section{Properties of PUR adhesive}

The resin and hardener were mixed at several ratios for curing the rubber particles into a composite sheet. Active contents of the hardener were determined by the back titration method of isocyanate groups [10, 11] which showed over $97 \%$ match to the stoichiometric value of toluene diisocyanate. This implied a relatively minor degradation due to humidity entrainment or other factors. Such hardener can be considered fast acting and effective in polyol condensation.

The resin appeared as a viscous opaque pasty liquid and was not fully soluble in organic solvents. Its TGA in air showed the $2.0 \mathrm{wt} . \%$ non-combustible residue. The nonvolatile residue in nitrogen atmosphere was substantially higher at 3.4 wt.\%. A completely opaque appearance and distinct insolubles in organic solvents suggested significant contents of inorganic fillers in the resin. The organic portion in the resin did appear to undergo dramatic transformations during the heat ramping, which resulted in several peaks of minor significance in the derivative curve. In order 
to estimate the amounts of other elements, the EDX analysis was performed on the resin. In addition to $\mathrm{C}$ and $\mathrm{O}$ at 66.58 and $31.71 \mathrm{wt} . \%$, significant amounts of $\mathrm{Ca}(1.01 \mathrm{wt} . \%), \mathrm{Cl}$ $(0.45 \mathrm{wt} . \%)$ and $\mathrm{Si}(0.25 \mathrm{wt} . \%)$ were detected. The elemental analysis data was not sufficient to accurately identify the inorganic fillers, however, the significant presence of $\mathrm{TiO}_{2}$, $\mathrm{ZnO}, \mathrm{Sn}$ derivatives and many other functionalized fillers could be ruled out with certainty.

The further analysis of the resin using FTIR showed a broad band of hydroxyl groups near $3500 \mathrm{~cm}^{-1}$ (Fig. 1). Several observations were made from the absorption bands in fingerprint and high frequency $(\mathrm{C}, \mathrm{N}, \mathrm{O}-\mathrm{H})$ stretching spectral regions. The most intense band near $1109 \mathrm{~cm}^{-1}$ is associated with $\delta(\mathrm{C}$ O-C) deformation vibrations [Socrates 2001]. The other characteristic bands are visible at $2971 \mathrm{~cm}^{-1} v_{a s}\left(\mathrm{CH}_{3}\right), 2927 \mathrm{~cm}^{-1}$ $v\left(\mathrm{CH}_{2}\right), 2870 \mathrm{~cm}^{-1} v_{s}\left(\mathrm{CH}_{3}\right), 1454 \mathrm{~cm}^{-1}$ and $1354 \mathrm{~cm}^{-1} \delta\left(\mathrm{CH}_{2}\right)$. Low intensity bands near $1601 \mathrm{~cm}^{-1}$ indicating the presence of aromatic $\mathrm{C}=\mathrm{C}$ and the bands at $1729 \mathrm{~cm}^{-1} v(\mathrm{C}=0), 1643 \mathrm{~cm}^{-1}$ (amide) and $3320 \mathrm{~cm}^{-1}$ (amide NH) showed a clear presence of carbamate groups in the resin. This implied that polyols underwent partial condensation reactions with isocyanates, forming the so-called prepolymers.

The molar mass of polyols which have hydroxyl groups as end groups was estimated by an end-group assay by adapting the standard ASTM E326-96 method [13]. As a very vague approximation the molar mass could approach $\sim 2000 \mathrm{~g} / \mathrm{mol}$. The actual molar mass of the prepolymers in the resin could be much higher, because the kinematic viscosity of the resin was recorded at $2120 \mathrm{cSt}$ at $40^{\circ} \mathrm{C}$. The vis- cosity of pure polypropylene glycol of $2000 \mathrm{~g} / \mathrm{mol}$, such as Polyglycol P-2000E $\mathrm{E}^{\mathrm{TM}}$ or similar polyether polyols, should be around $150 \mathrm{cSt}$ [14], i.e. much lower. Inorganic fillers and other resin components might thicken it up somewhat, but the most thickening was caused by prepolymers. Higher molar mass components might increase viscosity significantly, nevertheless substantial contents of thickening material would be needed [15. However, the extent of condensation, the size and concentration of prepolymers or other characteristics have not yet been studied in more detail.

The FTIR spectrum of the cured PUR adhesive showed the rest of expected functionalities: at $3295 \mathrm{~cm}^{-1}$ amino group $v$ mode $(\mathrm{N}-\mathrm{H})$; at $2970 \mathrm{~cm}^{-1}$ and $2868 \mathrm{~cm}^{-1}$ alkyl vibrations $(\mathrm{C}-\mathrm{H})$; at $1727 \mathrm{~cm}^{-1}$ carbonyl group $v$ mode $(\mathrm{C}=\mathrm{O})$ of urethane and those of urea at $1640 \mathrm{~cm}^{-1}$; at $1534 \mathrm{~cm}^{-1}$ amide II vibrations $(\delta \mathrm{N}-\mathrm{H}, v \mathrm{C}-\mathrm{N})$; at $1225 \mathrm{~cm}^{-1}$ amide III vibrations $(\delta \mathrm{N}-\mathrm{H}, v \mathrm{C}-\mathrm{N})$; at $1090 \mathrm{~cm}^{-1}$ ether linkage vibrations (C-O-C).

The Raman spectra confirmed the initial FTIR findings (Fig. 2). Several high intensity bands in the high frequency region near $2872 / 2933 \mathrm{~cm}^{-1}$ are related to the symmetric and asymmetric stretching vibrations of $\mathrm{CH}_{2}$ and $\mathrm{CH}$ groups in the alkyl chains. Other characteristic alkyl chain bands are visible at $2974 \mathrm{~cm}^{-1} v_{a s}\left(\mathrm{CH}_{3}\right), 1455 \mathrm{~cm}^{-1}$ and $1346 \mathrm{~cm}^{-1}$ $\delta\left(\mathrm{CH}_{2}\right), 1086 \mathrm{~cm}^{-1} v(\mathrm{C}-\mathrm{C})$. The presence of aromatic groups is visible from the $3057 \mathrm{~cm}^{-1}$ band associated with the $=\mathrm{C}-\mathrm{H}$ stretching vibration and $1601 \mathrm{~cm}^{-1} v(\mathrm{C}=\mathrm{C})$. Low intensity bands at $2239 \mathrm{~cm}^{-1} v(\mathrm{NCO})$ are consistent with the presence of unreacted isocyanate.

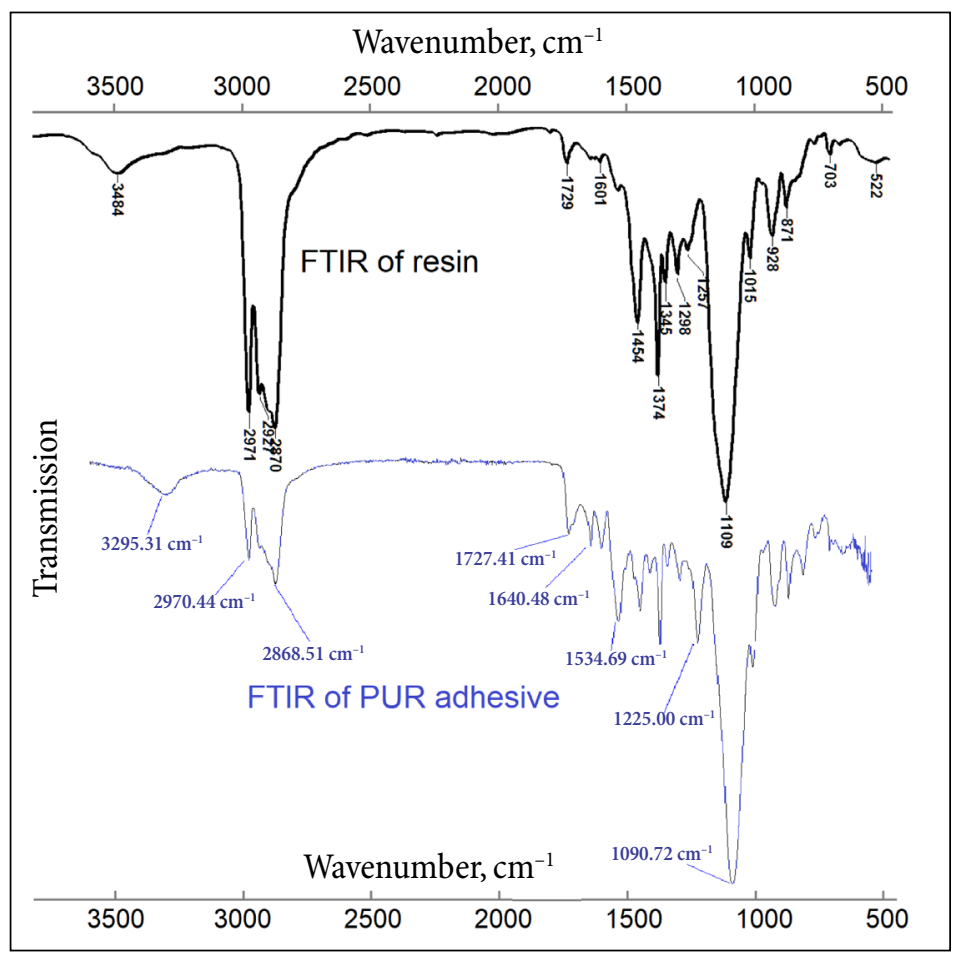

Fig. 1. Infrared spectrum of the polyether-based resin before adding the TDI hardener (top) and the spectrum of the cured PUR adhesive (bottom) 


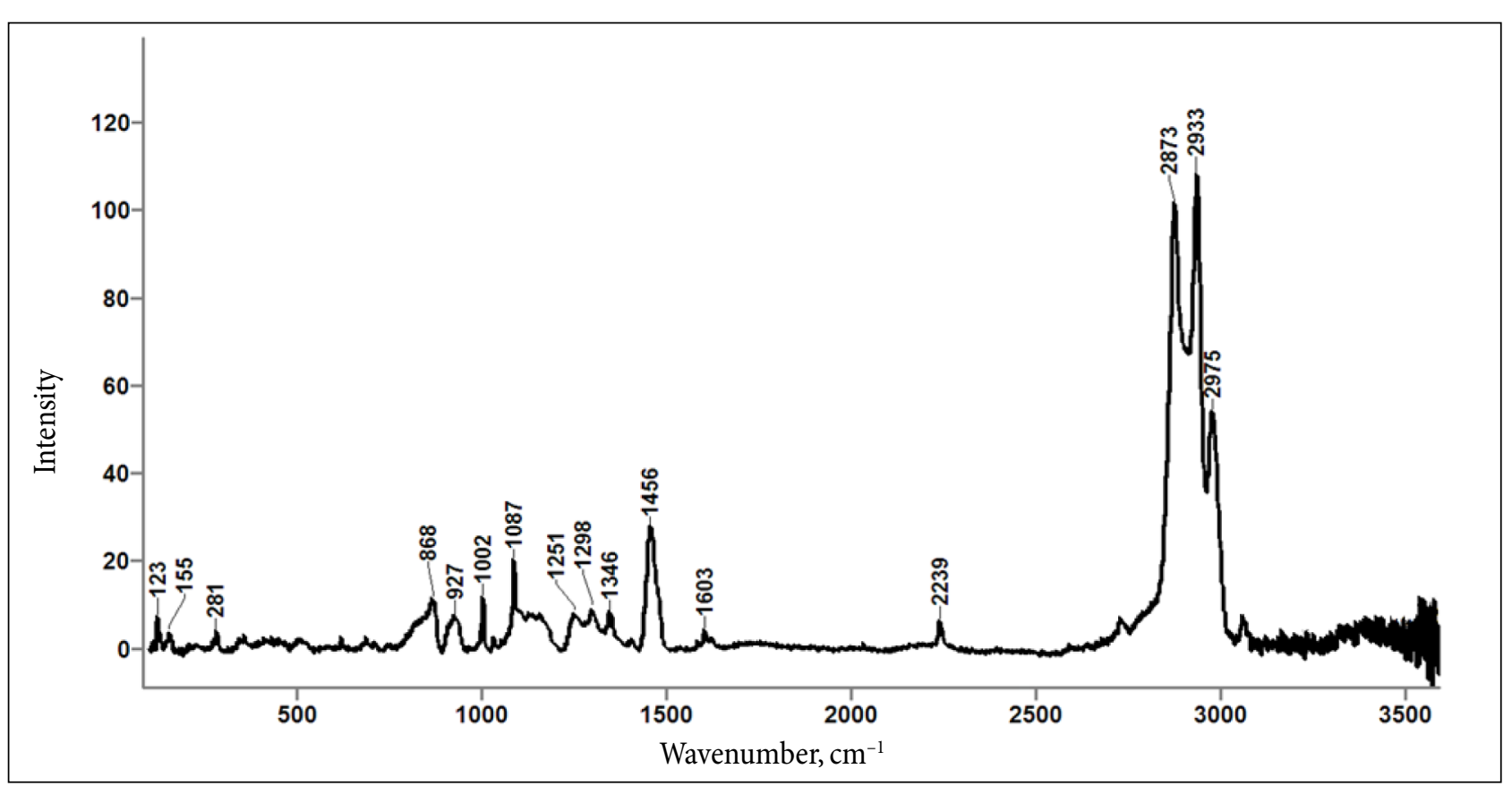

Fig. 2. Raman spectrum of the polyether-based resin used to formulate the PUR adhesive for rubber composites

The NMR analysis was also performed to learn more details about the type of polyol, used in the resin, see Fig. 3. The spectra showed ${ }^{1} \mathrm{H}$ NMR (DMSO- $\left.\mathrm{d}_{6}, \delta \mathrm{ppm}\right): 1.03(\mathrm{~d}$,

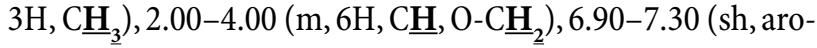
matic $\underline{\mathrm{CH}})$. The $\mathrm{EO} / \mathrm{PO}$ ratio was calculated using the relative integration values of the $\mathrm{PO}$ methyl peaks, by also factoring the $\mathrm{EO}$ and $\mathrm{PO}$ representation by the methylene and methine peaks. The EO/PO ratio was found to approach $1 / 1$ in the resin. Such level of EO moieties could increase hydrophilicity of the cured PUR adhesive.

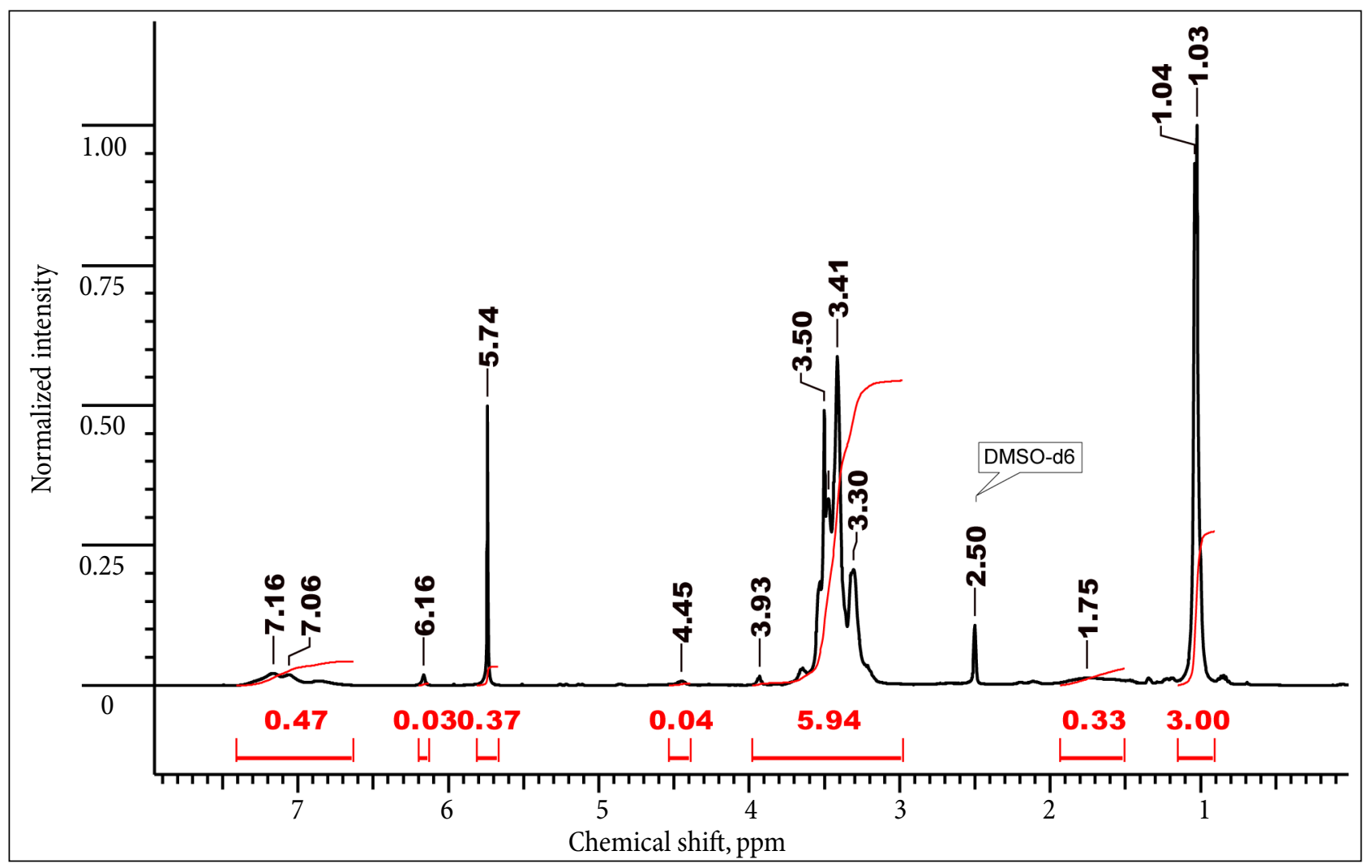

Fig. 3. NMR spectra ('H) of the polyether-based resin used to formulate the PUR adhesive for rubber composites 
Consequently, it could be deduced that the resin was produced by partially reacting a high excess of hydroxylterminated polyalkylene glycol (i.e. polyether polyol) with aromatic isocyanates to form some prepolymers. Inorganic fillers and supplemental additives were also blended into the mixture, resulting in the resin, used for this study.

A series of PUR adhesives was obtained by mixing the resin with the TDI hardener at various ratios. After the curing for $4 \mathrm{~h}$ at $60^{\circ} \mathrm{C}$, the main properties were determined, see Table 1. Concentration limits for the TDI hardener could be established even by visual evaluation. When $25 \mathrm{wt} . \%, 30 \mathrm{wt} . \%$ or higher ratio of the TDI hardener was used, the PUR adhesive would not form into a homogeneous mixture after curing for $4 \mathrm{~h}$ at $60^{\circ} \mathrm{C}$. On the other end, at $5 \mathrm{wt} . \%$ TDI hardener the mixture would not solidify completely, resulting in a pasty texture. Therefore, the functional range of the TDI hardener : resin ratios was apparent at 10:90 through 20:80.

The tensile properties of the PUR adhesive depended on the ratios very significantly. A higher ratio of the TDI hardener resulted in a better tensile strength, Young's modulus in particular. The elongation went down significantly, however. The compressive properties did not vary as dramatically, just the compressive Young's modulus followed the trend, similar to that of the tensile Young's modulus.
The TDI hardener : resin ratio of 15:85 could be considered a compromise between the Young's modulus and elongation/compression. However, due to the significant effects on physical mechanical properties, formulations with 10:90 and 20:80 ratios should not be disregarded.

\section{Properties of rubber particles}

Two feedstocks of rubber particulate, which were selected for the composite formation, represented two main varieties of rubber from ELT. Most often ELT recycling begins with mechanical grinding, during which crumbs of Ground Tire Rubber (GTR) are produced. In this study GTR feedstock from predominantly passenger car tires was selected, using a granulometric fraction of 2-3 $\mathrm{mm}$ in size. The other rubber particulate represented a different type of ELT rubber. Truck tires are often retreaded, when the original tread is buffed off to produce the so-called 'buffings' in order to apply a new tread. In this study truck two batches of tire tread buffings were employed. In order to highlight the importance of fine particles, mostly Sieved Tread Buffings (STB) were employed. In some cases, Whole Tread Buffings (WTB) were also used. Appearance of all three rubber particle batches is shown in Fig. 4 .

At 2 to $3 \mathrm{~mm}$ in size, GTR represented relatively coarse particles for composite synthesis. Buffings (WTB) were much

Table 1. Physical and mechanical properties of cured PUR adhesives, formulated by varying the ratio between the TDI hardener and the resin, based on polyether polyol

\begin{tabular}{|c|c|c|c|c|c|}
\hline Adhesive formulations $\rightarrow$ (hardener : resin, wt.\%:wt.\%) & $5: 95$ & $10: 90$ & $15: 85$ & $20: 80$ & 25:75 and $30: 70$ \\
\hline TDI hardener, wt.\% & 5 & 10 & 15 & 20 & 25 and 30 \\
\hline Resin, wt.\% & 95 & 90 & 85 & 80 & 75 and 70 \\
\hline \multicolumn{6}{|l|}{ Physical-mechanical properties } \\
\hline Density, $\mathrm{g} / \mathrm{cm}^{3}$ & 0.8566 & 0.8687 & 0.8830 & 0.8818 & incompatible \\
\hline Tensile strength $\sigma \mathrm{R}, \mathrm{MPa}$ & pasty & 0.44 & 0.91 & 1.01 & incompatible \\
\hline Young's modulus $\mathrm{E}, \mathrm{MPa}$ & pasty & 0.615 & 2.92 & 5.39 & incompatible \\
\hline Elongation XR, \% & pasty & 79.4 & 50.4 & 31.9 & incompatible \\
\hline Compressive strength at break $\sigma^{*}, \mathrm{MPa}$ & pasty & 9.23 & 9.2 & 9.19 & incompatible \\
\hline Compressive Young's modulus E*, MPa & pasty & 2.36 & 6.78 & 9.16 & incompatible \\
\hline Compression at break, XR*, \% & pasty & 93.7 & 80.7 & 76.3 & incompatible \\
\hline
\end{tabular}
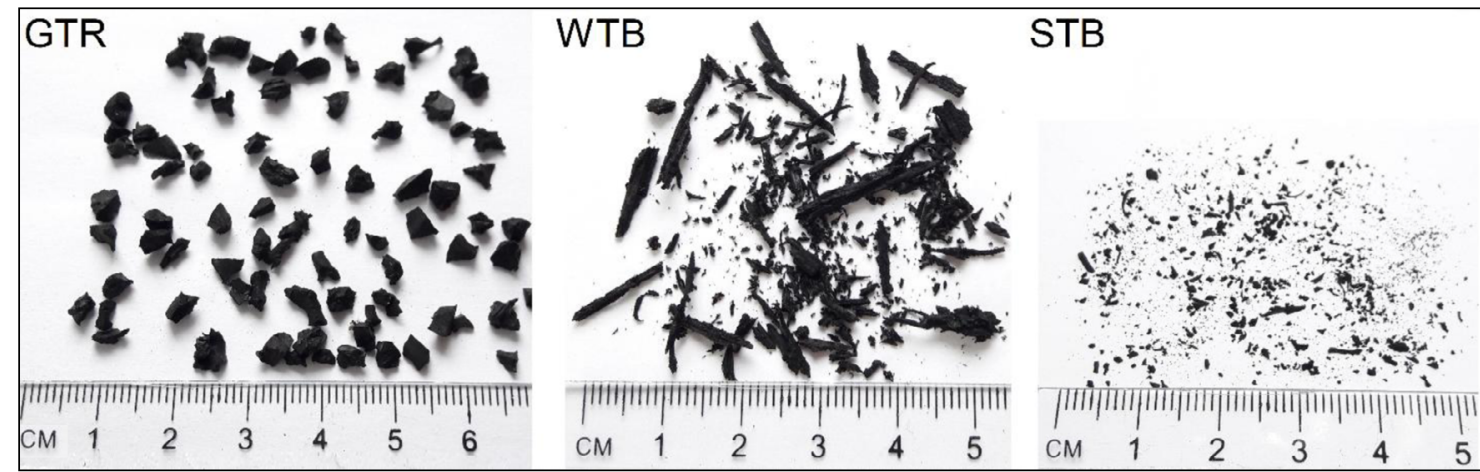

Fig. 4. A visual appearance of the rubber particle batches, used for composite formation. Left: Ground Tire Rubber (GTR) from passenger car tires. Center: Whole Tread Buffings (WTB) from truck tires. Right: Sieved Tread Buffings (STB) from truck tires 
more diverse in size and shapes than GTR. The average aspect ratio of WTB was much larger than that of GTR. Their granulometry also varied greatly (Table 2). Since the particle size distribution among GTR, STB and WTB is not similar at all, it might be expected that their differences would play a major role on the technical properties of synthesized composites. However, other aspects of rubber feedstocks should not be disregarded. From the visual appearance it can be expected that GTR, WTB and STB should have a rather smooth surface. The SEM study was performed to look into the main differences between the topography of GTR and the buffings.

The surfaces appeared relatively flat on a micro-scale with peaks and valleys of just several microns in height (Fig. 5). The surface of GTR particles, however, appeared somewhat smoother than that of STB, which appeared to have some step-like structures present. Such type of deformation could occur due to the severe mechanical shear when the tread was buffed. Assuming the perfect wetting and uniform distribution of the PUR adhesive, different roughness would lead to major differences in the surface area, which would directly affect the thickness of the adhesive film. Thinner films would usually lead to faster reactions between interfaces [16, 17], but in this case the bonding between the PUR adhesive and rubber matrix should not be significantly affected. Another major feature was deep but narrow cracks of several microns in length on the GTR rubber. Such cracks were not identified on the STB particles.

More differences were possible between GTR and STB, just not evident from the SEM images. GTR was expected to contain more of Styrene-Butadiene Rubber (SBR) than other rubbers types either blended together, or mixed as crumbs of individual rubber. Nevertheless, a possibility of abundance in other rubber types should not be disregarded, because Natural Rubber (NR) is widespread in tire treads and other structural components, butadiene rubber is present in tire sidewalls, while butyl and chlorobutyl rubbers are typically used for inner liners. All of these could make

Table 2. A list of the granulometric fractions on the US Standard Mesh scale and the particle size distribution of utilized rubber particle batches

\begin{tabular}{c|c|c|c|c|c}
\hline Fraction & \multicolumn{2}{|c|}{ Size of particles in the fraction } & \multicolumn{3}{c}{ Fraction amounts in the particle batch, wt.\% } \\
\hline & Smallest & Largest & GTR & WTB & STB \\
\hline 5 Mesh & $3.35 \mathrm{~mm}$ & $4.75 \mathrm{~mm}$ & $<1 \%$ & $<1 \%$ & $2.8 \pm 2.1$ \\
\hline 6 Mesh & $2 \mathrm{~mm}$ & $3.35 \mathrm{~mm}$ & 99 & 24 & $14.3 \pm 1.9$ \\
\hline 10 Mesh & $850 \mu \mathrm{m}$ & $2 \mathrm{~mm}$ & $<1$ & 50 & $44.5 \pm 2.5$ \\
\hline 20 Mesh & $425 \mu \mathrm{m}$ & $850 \mu \mathrm{m}$ & $\sim 0$ & 20 & $18.7 \pm 1.5$ \\
\hline 40 Mesh & $250 \mu \mathrm{m}$ & $425 \mu \mathrm{m}$ & $\sim 0$ & 4 & $8.7 \pm 2.7$ \\
\hline 60 Mesh & $180 \mu \mathrm{m}$ & $250 \mu \mathrm{m}$ & $\sim 0$ & 1 & $10.01 \pm 2.8$ \\
\hline 80 Mesh & n.d. & $180 \mu \mathrm{m}$ & $\sim 0$ & 1 & Mostly round \\
\hline Aspect ratio & & Mostly round & Often very elongated
\end{tabular}
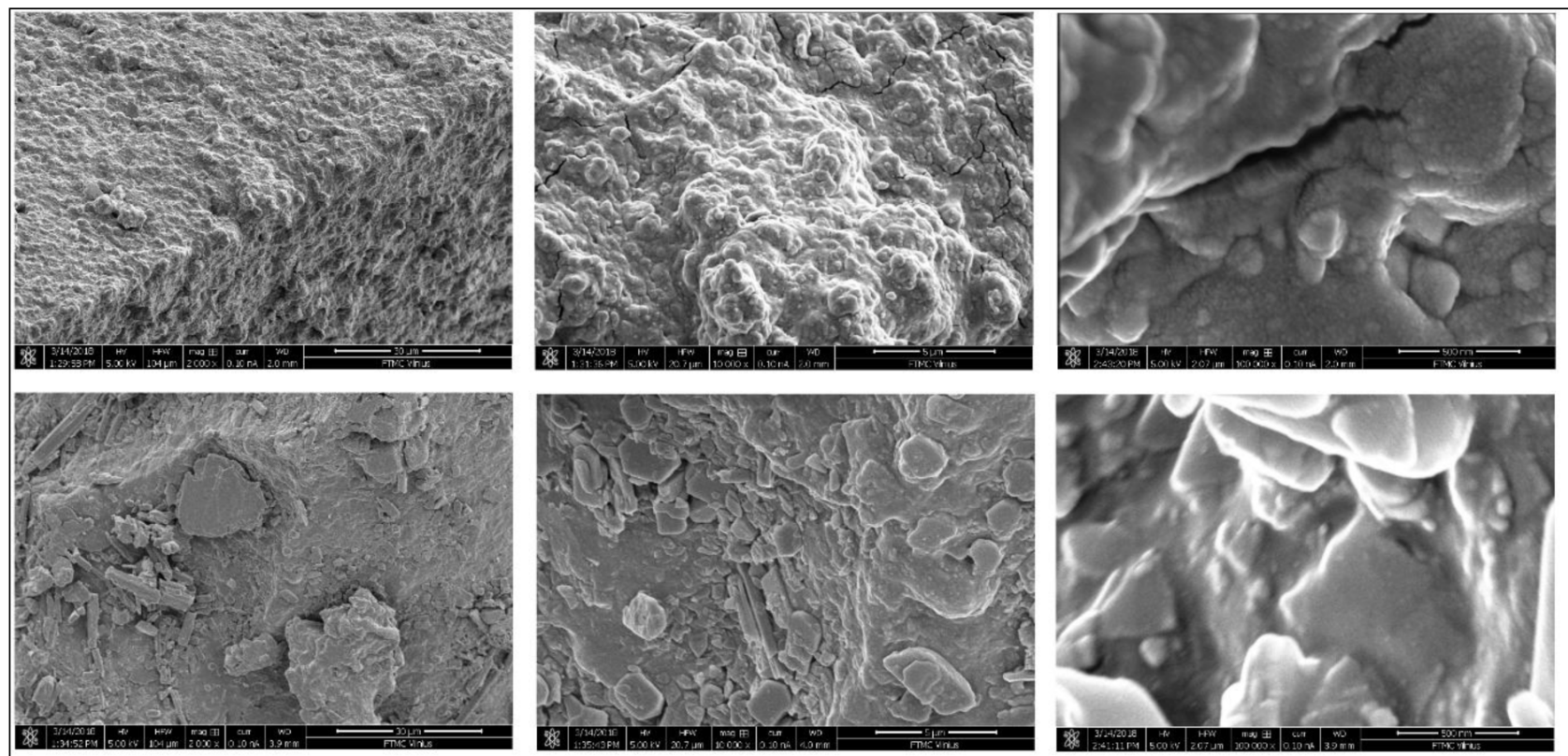

Fig. 5. Topography of rubber particles per SEM imaging. Top row: GTR; bottom row: STB. From left to right: $2000 \times 10000 \times$ and $100000 \times$ magnifications 
their way into GTR, since the ELT recycler would not segregate the incoming waste rubber into individual streams. In the case of STB, the predominant rubber type should be NR, typically blended with SBR at 4:1 ratio. Clearly, with so many physical and chemical differences between GTR and STB it would be hard to expect a good agreement between the properties of their composites.

\section{Curing of composite sheets}

A series of composite sheets was formulated and cured at various temperatures, leading to some variation in appearance. Coarse rubber particles were clearly distinct (Fig. 6 ). Since the rubber portion contained different amounts of large fractions, the surface texture varied very significantly. Large crumbs were protruding from the sheet, formulated with GTR. However, the surface was much smoother when the $1+1$ mix of coarse and fine rubber $(\mathrm{GTR}+\mathrm{STB})$ was utilized. Since coarse particles were abundant in WTB, the sheet surface appeared quite rough in agreement with expectations.

Not just the granulometry of rubber particles could affect the appearance of the composite sheet. The amount of the PUR adhesive also showed a major influence (Fig. Ø]. Dif- ferences could be visible even among the sheets of fine particles. Their appearance depended on the amount of the PUR adhesive. The sheets containing $40 \mathrm{wt} . \%$ of the adhesive were much smoother than those with $15 \mathrm{wt} . \%$. Other aspects could also play a role in filling up the voids or pooling near the surface. Therefore, the thin cross-sections of the sheets were cut off and inspected using SEM.

The internal morphology of the composites turned out less diverse than their surface topography. Most composites showed clearly resolved voids within the well-distinguished PUR-rubber continuum (Fig. 8). Judging from the shape of the voids, they appeared to be embedded as oddly-shaped bubbles within the continuum of the rubber and the PUR adhesive. These voids did not resemble the gaps between the aggregated rubber particles. In fact, it was nearly impossible to distinguish between the rubber particles and the PUR adhesive under the given SEM regime, since their surfaces had been sputtered with approx. a $5 \mathrm{~nm}$ Au layer for improved electrical conductivity. Maybe the sheet with $15 \mathrm{wt} . \%$ could show some of segregation between the rubber and the PUR adhesive, judging from the variation in tint, but such supposition would be highly speculative. The sheets with $30 \mathrm{wt} . \%$ and $40 \mathrm{wt} . \%$ would not even show tint variation.

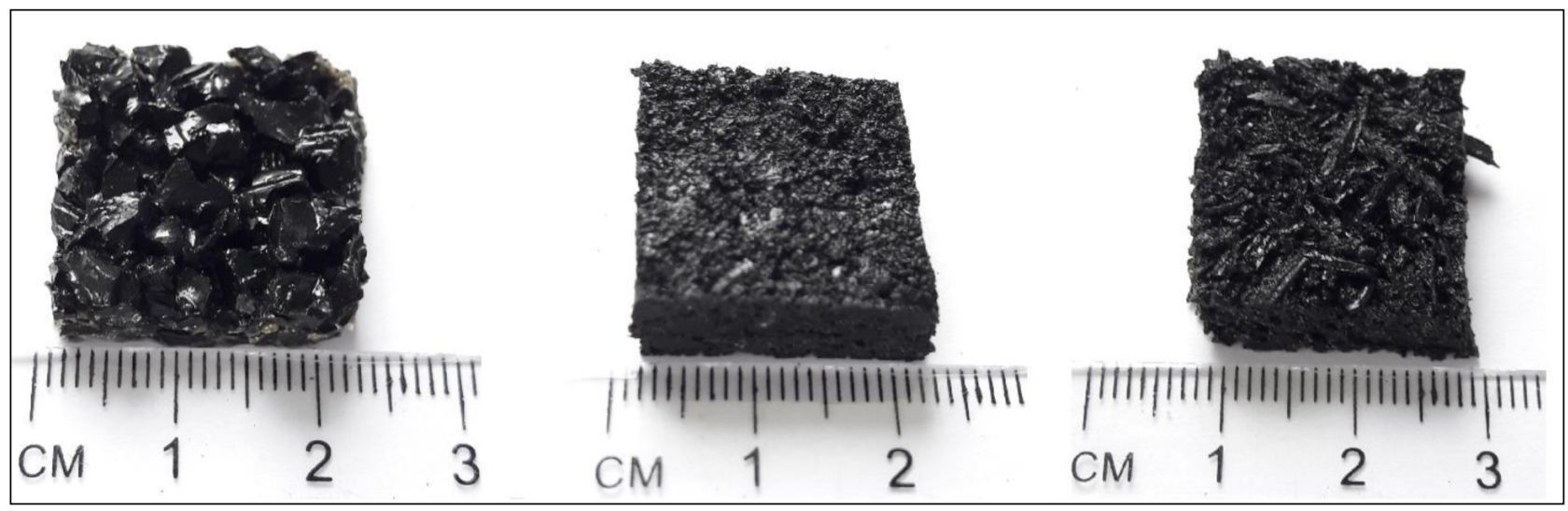

Fig. 6. Photographs of the composite sheets, utilizing GTR (left), 1+1 mix of GTR+STB (center) and WTB (right). Formulated with the 30 wt.\% PUR adhesive at the $15: 85$ ratio of hardener to resin and cured for $4 \mathrm{~h}$ at $60^{\circ} \mathrm{C}$

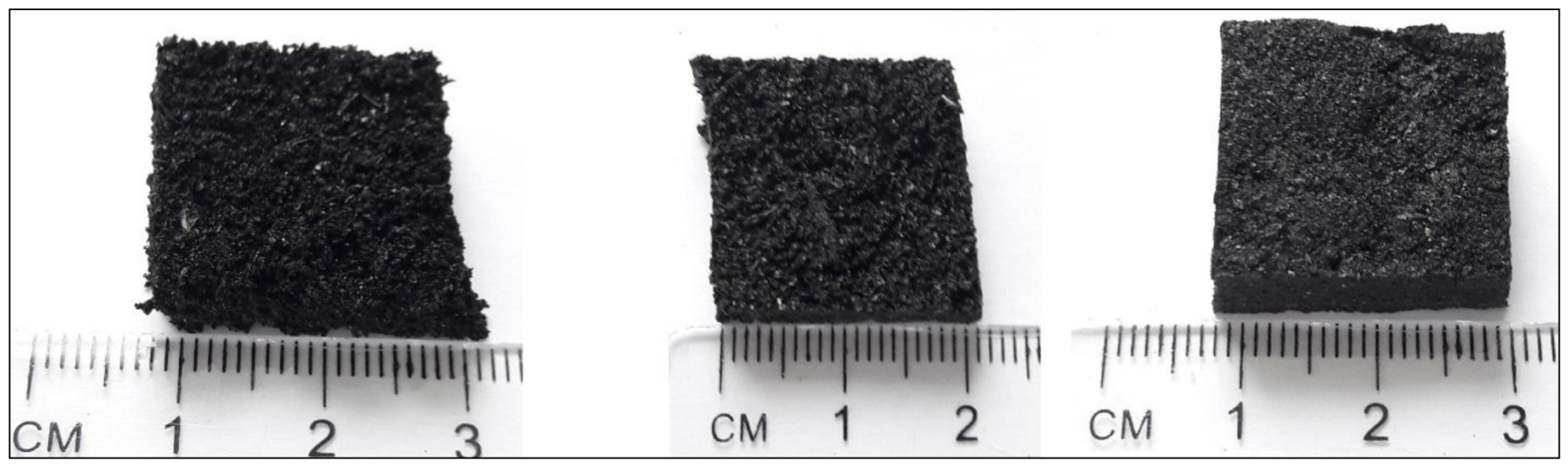

Fig. 7. Photographs of the composite sheets, formulated with fine rubber (STB) and $15 \mathrm{wt} . \%$ (left), 30\% wt.\% (center) and $40 \mathrm{wt} . \%$ (right) of the PUR adhesive using the $15: 85$ ratio of hardener to resin. Cured for $4 \mathrm{~h}$ at $60^{\circ} \mathrm{C}$ 

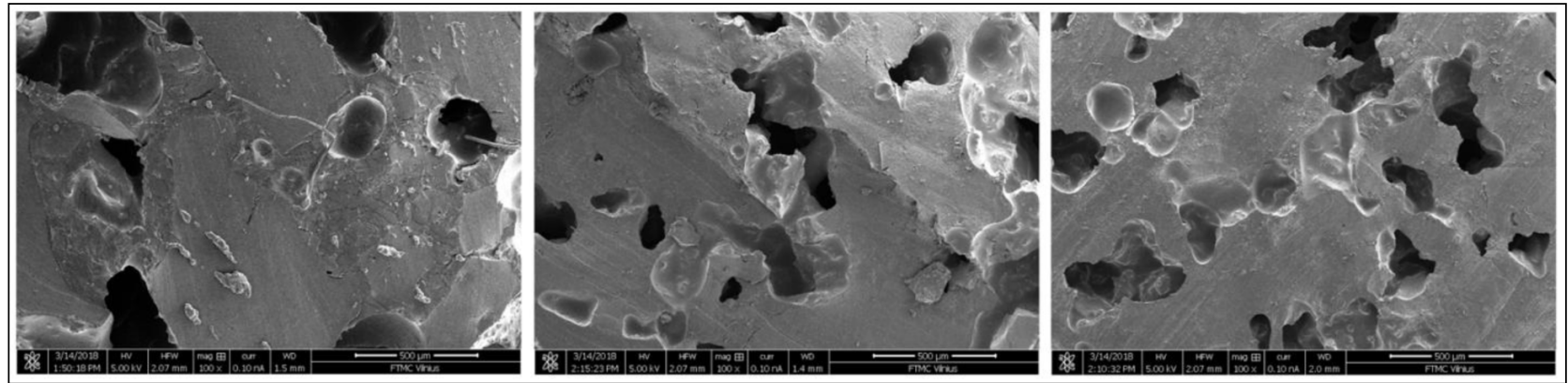

Fig. 8. Voids within the PUR-rubber continuum, as demonstrated by SEM images of the cross sections from the composite sheets with STB at 15 wt. $\%$ (left), $30 \%$ wt. $\%$ (center) and $40 \mathrm{wt} . \%$ (right) of the PUR adhesive using the 15:85 ratio of hardener to resin. Cured for $4 \mathrm{~h}$ at $60^{\circ} \mathrm{C}$

However, not in every case the PUR-rubber continuum was easily distinguishable. The composite sheets made of larger crumbs of rubber showed a more distinct segregation between the elastomer particles and PUR adhesive (Fig. 9). The voids between the aggregated rubber particles could be resolved from the bubbles, as in the case of the sheet with two mixed rubbers (GTR+STB). Some specimens did not even exhibit a distinguishable continuum phase, in particular the sheet made of WTB. This suggested that the adhesive was not able to wet the rubber particles before curing on its own within separate pools surrounded by poorly-glued rubber particles.

The SEM findings suggested that the most favourable mechanism of the composite formation involved thorough wetting of rubber particles with the PUR adhesive, followed by completion of curing. The strength of bonds between the PUR adhesive and rubber particles was not less important, however, the influence of wetting should not be disregarded.

\section{Tensile and compressive properties of composites}

The above aspects had a varying significance on the integrity of the obtained composite sheets. Therefore, tensile strength, elongation, Young's modulus and other extensometric properties were measured. Initially, the effects of the PUR adhesive amounts were evaluated (Fig. 10). The lowest amount of the PUR adhesive, which made it pos- sible to produce a manageable composite sheet with STB, was achieved at $10 \mathrm{wt} . \%$ with sufficient repeatability. More PUR adhesive assured a better integrity of the composite sheets, as measured by tensile properties. At lower concentrations of the PUR adhesive its amounts were most likely not sufficient to fill in the void volume, because either all adhesive was consumed to fully coat rubber particles, or adhesive pooled in segregated zones. Since vigorous mixing was applied, the latter case was less likely.

The influence of PUR adhesive contents on the compressive properties of composite sheets was also investigated (Fig. 11). The data showed that a lower amount of the PUR adhesive was not as detrimental to the compressive properties as in the case of tensile performance. Satisfactory compressive properties could be achieved with as little as $10 \mathrm{wt} . \%$ PUR adhesive. This was in line with the findings of other researchers [4] 6 , , who had established concentrations of the PUR adhesive in the GTR composites below $20 \mathrm{wt} . \%$ as optimum for physical-mechanical performance. It should be noted that the above reports involved a much more extensive optimization of resin and hardener formulations as well as curing conditions, compared to this study. If necessary, such optimization exercises might lead to a significant reduction of the PUR adhesive demand.

The effects of curing temperatures were also investigated in this study to establish the most favourable thermal regime (Fig. 12). The best tensile properties were achieved
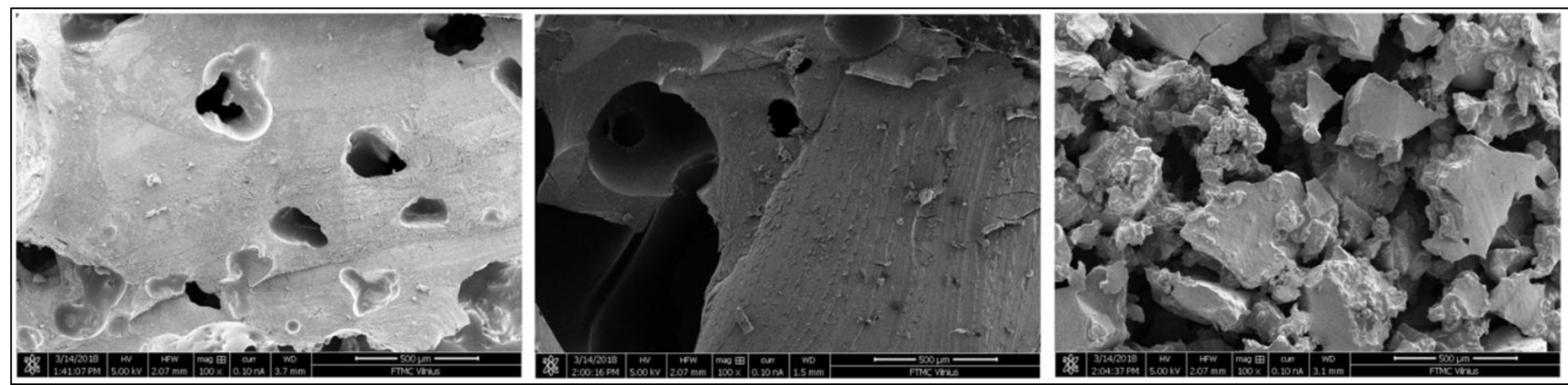

Fig. 9. Segregation of rubber particles from the PUR adhesive, as demonstrated by SEM images of the composite sheet cross sections, utilizing GTR (left), 1+1 mix of GTR+STB (center) and WTB (right). Formulated with the $30 \mathrm{wt} \%$ PUR adhesive using the 15:85 ratio of hardener to resin and cured for $4 \mathrm{~h}$ at $60^{\circ} \mathrm{C}$ 


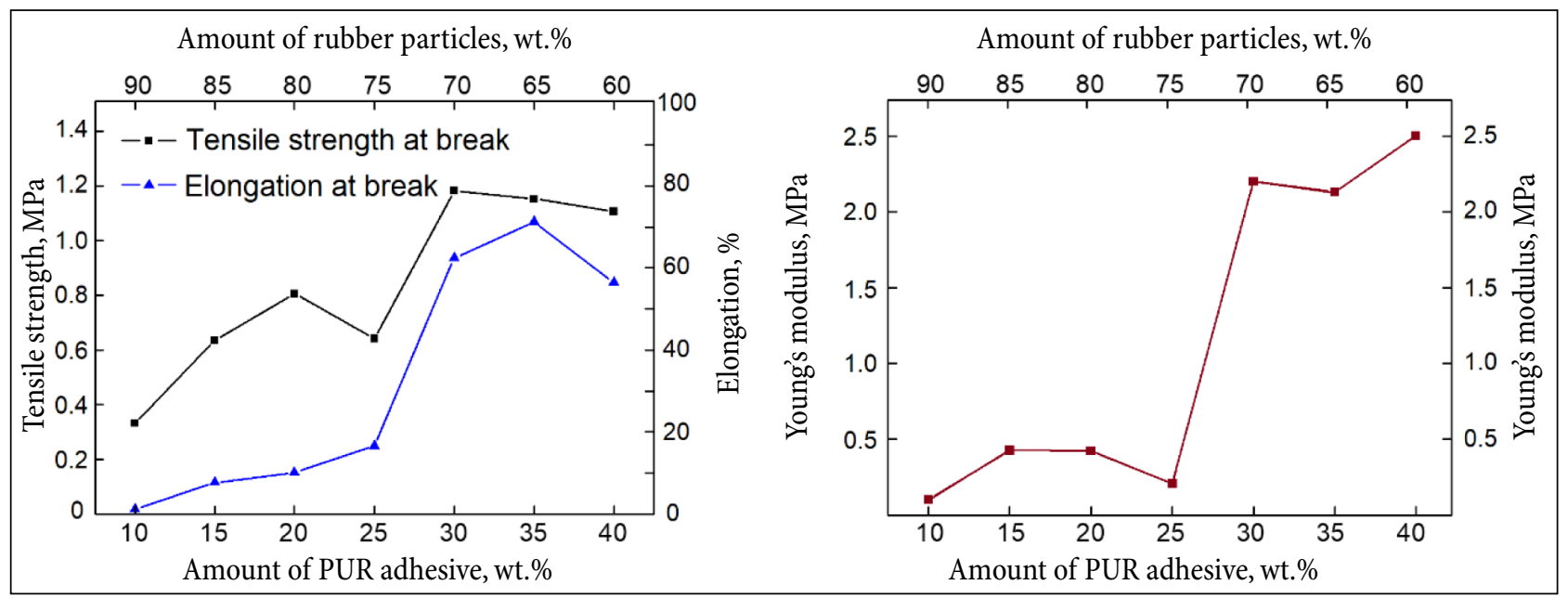

Fig. 10. Influence of the ratio between the PUR adhesive and STB on tensile strength and elongation, both at break (left). The influence on Young's modulus (right). The ratio of TDI hardener : resin at 15:85, cured for $4 \mathrm{~h}$ at $60^{\circ} \mathrm{C}$

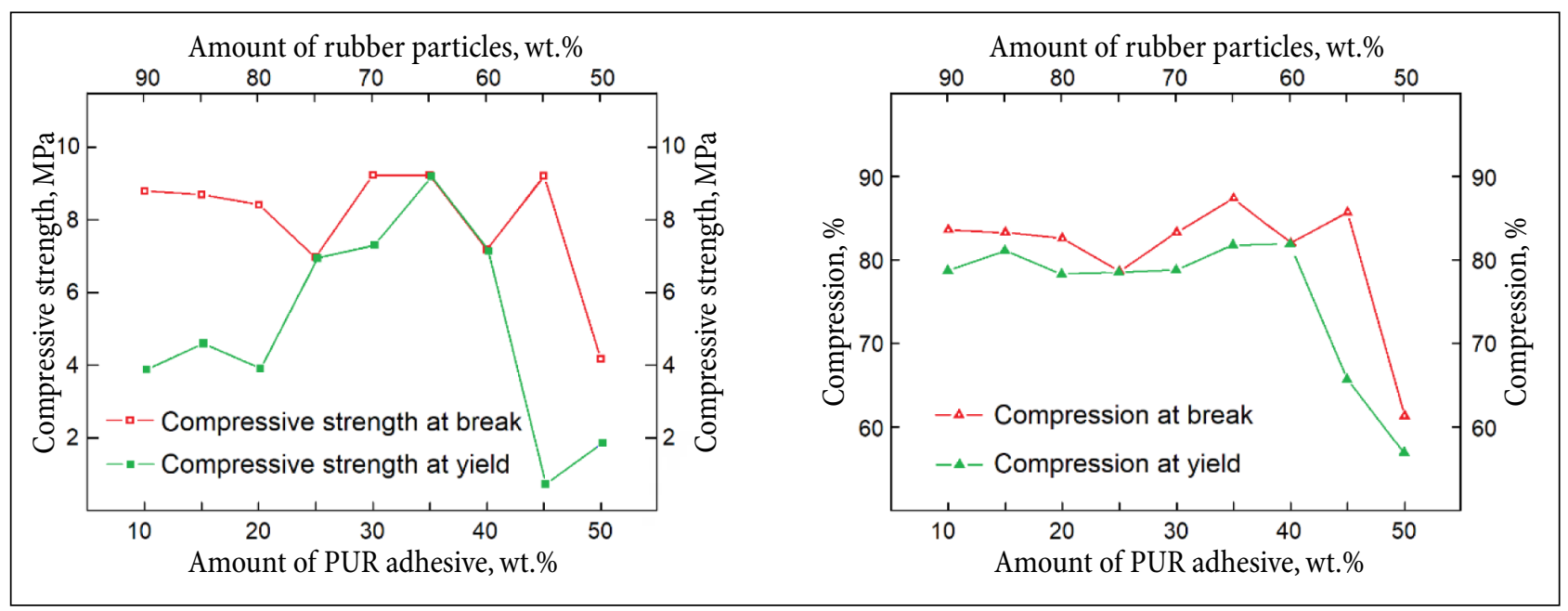

Fig. 11. Influence of the ratio between the PUR adhesive and STBs on compressive properties of cured composite sheets: compressive strength (left) and compression (right). The ratio of TDI hardener : resin at 15:85, cured for $4 \mathrm{~h}$ at $60^{\circ} \mathrm{C}$

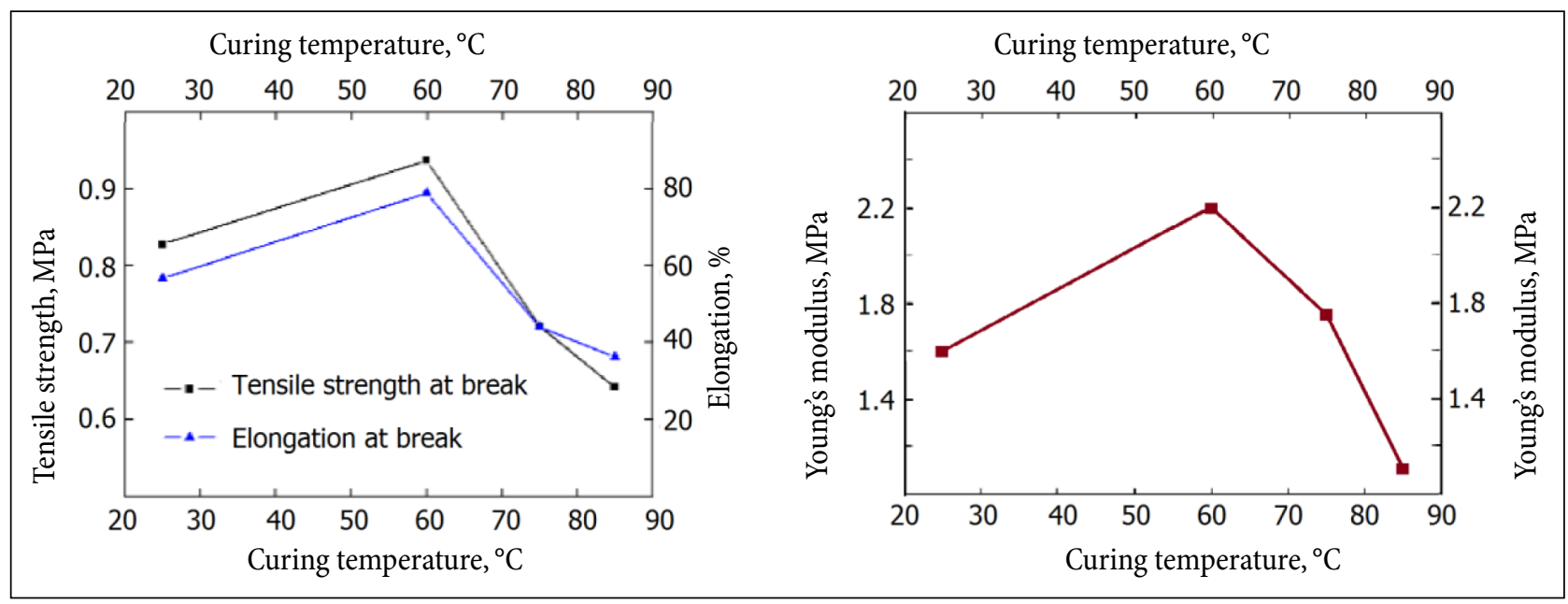

Fig. 12. Effects of curing temperatures (curing durations of $4 \mathrm{~h}$ ) on the tensile properties of the composite sheets with $60 \mathrm{wt} \%$ STB and 40 wt.\% PUR adhesive, using the 15:85 ratio of TDI hardener : resin 
after curing at $60^{\circ} \mathrm{C}$. When cured at $25^{\circ} \mathrm{C}$, the properties were somewhat better than those after curing at 75 or $85^{\circ} \mathrm{C}$. The drop in tensile performance might be a result of fast congealing of the PUR adhesive, before it spread out through the mixture and wet the rubber particles. It could be stated with certainty that curing at temperatures below $60^{\circ} \mathrm{C}$ would not damage tensile properties as much as curing at higher temperatures.

The effects of curing temperatures were less evident on compressive properties (Fig. 13). In fact, the compression at break or at yield remained nearly independent of the curing temperature. The only significant drops in compressive strength were observed after curing at $85^{\circ} \mathrm{C}$. Otherwise, all measured compressive properties were similar for the curing temperatures in the interval from 25 to $75^{\circ} \mathrm{C}$.

The data on tensile and compressive performance confirmed the findings of other researchers that rubber particle composites could be successfully cured using toluene diisocyanate and prepolymer-containing resin at temperatures of $60^{\circ} \mathrm{C}$ or lower within technologically reasonable curing durations. In this study the best tensile and compressive properties were obtained at PUR adhesive concentrations of 30 and $40 \mathrm{wt} . \%$. Further optimization of curing conditions, hardener selection and incorporation of supplemental additives could change this concentration significantly, because many additional factors might still be important. For example, it might be expected that rubber particles would swell in the presence of the PUR adhesive [8] and make the bonding more effective. Surface morphology differences might also play a significant role in swelling of rubber particles, but they could affect wetting and void filling even more. If rubber particles had highly uneven surfaces, many more voids might remain without being filled with adhesives [18]. On the other hand, rough particle surfaces should increase the total area of bonding [19,20], which would apply to many systems, including the interface between the rubber and the PUR adhesive. This factor might improve the strength and other physical mechanical properties of the composites. Therefore, further microscopy and extensometry studies involving different adhesive formulations and curing regimes would be highly useful for improvement in ELT rubber recycling into composites and other materials of a higher added value.

\section{CONCLUSIONS}

Using rubber particles and PUR adhesives, a great variety of composite materials can be obtained from polymeric foams to flexible sheets to rigid blocks. Unfortunately, it remains unclear which aspects of rubber particle morphology, PUR adhesive composition or curing conditions are the most important for the final physical and mechanical characteristics. The main purpose of the experiments in this investigation was to improve the understanding about the control of physical and mechanical properties of rubber particle composites by varying the formulation and curing conditions of the selected PUR adhesive. Several major conclusions have been drawn from the findings.

- Properties of rubber particles are important for PUR composites, but they do not appear as the most controlling factor for the tensile and compressive properties of the composite.

- Curing at higher temperatures damages tensile properties more than curing at lower temperatures.

- Compared to tensile properties, compressive properties are significantly less dependent on curing temperatures.

- Void formation mechanisms in composites are very important for tensile and compressive properties.

- Wetting of rubber particles with the PUR adhesive, followed by completion of the curing process along with the formation of strong bonds between the PUR adhesive and rubber particles, might represent an ideal mechanism to achieve the best tensile and compressive properties.

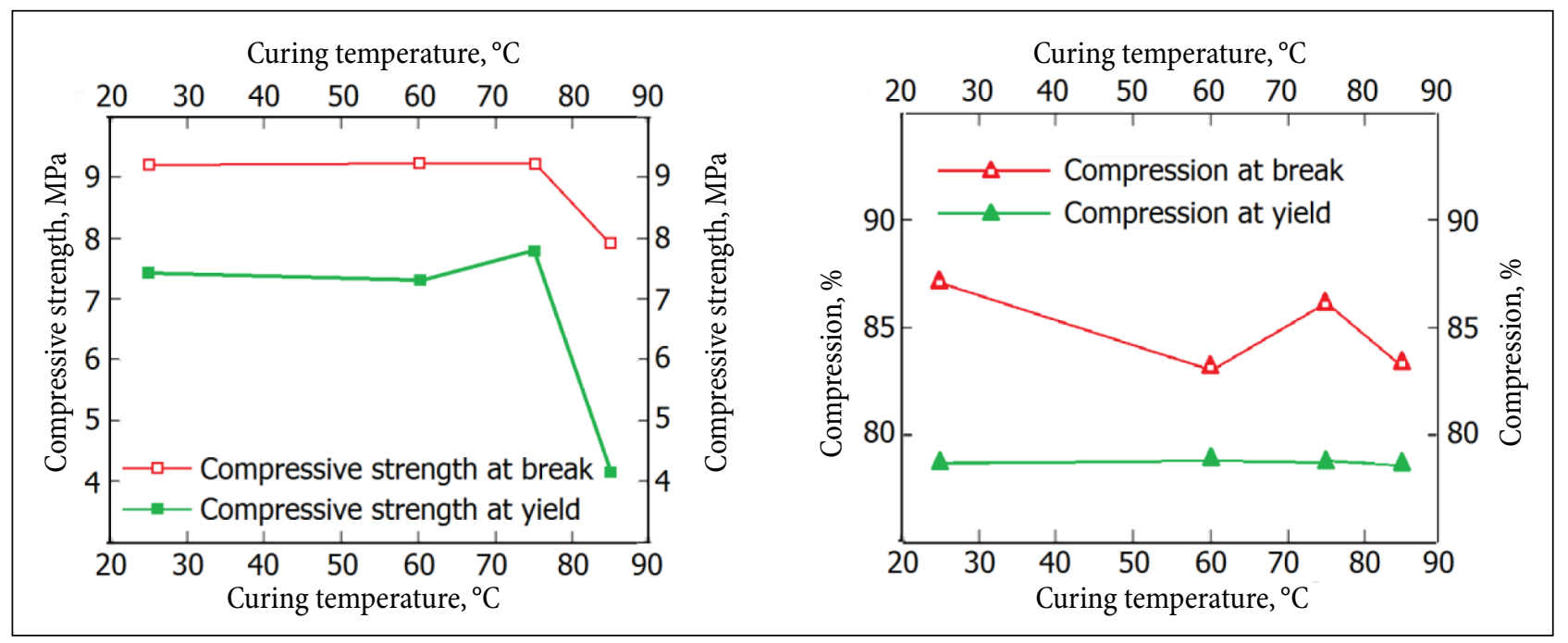

Fig. 13. Effects of curing temperatures (curing durations of $4 \mathrm{~h}$ ) on the compressive properties of composite sheets, using the 15:85 ratio of TDI hardener : resin 
- Better understanding how to control physical and mechanical properties of such composites will significantly contribute to value-added utilization of ELT as well as environmental and societal benefits.

\section{ACKNOWLEDGEMENTS}

Budgetary funding of FTMC was used to support this investigation. Research concepts originated during the OzoRubber project E!9962, coordinator Nizor Ltd. (Israel). Free samples from Devulco and Gumos Technologijos (Lithuania) along with their technical assistance are greatly appreciated. Experimental efforts of Artur Sosnovski (from Vilnius University) are sincerely acknowledged.

Received 21 March 2018 Accepted 4 April 2018

\section{References}

1. M. Sienkiewitz, J. Kucinska-Lipka, H. Janik, A. Balas, Waste Manag., 32, 1742 (2012).

2. L. Imbernon, S. Norvez, Eur. Polym. J., 82, 347 (2016).

3. X. Zhang, Z. Lu, D. Tian, H. Li, C. Lu, J. Appl. Polym. Sci., 127(5), 4006 (2013).

4. P. Cachaço, A. Guilherme, M. D. Afonso, M. L. Pinto, J. Appl. Polym. Sci., 129(5), 2873 (2013).

5. J. K. Kim, Korea Polym. J., 5(4), 241 (1997).

6. W. W. Sułkowski, A. Danch, M. Moczyński, A. Radoń, A. Sułkowska, J. Borek, J. Therm. Anal. Calorim., 78(3), 905 (2004).

7. R. Plesuma, L. Malers, IOP Conf. Ser.: Mater. Sci. Eng., 111(1), 012004 (2016).

8. K. Petrauskas, V. Žaržojūtè, A. Jukna, S. Asadauskas, Chemija, 28(4), 193 (2017).

9. R. Makuška (ed.), Synthesis and Characterization of Polymers, VU Leidykla, Vilnius (2006) [in Lithuanian].

10. B. S. Karten, T. S. Ma, Microchem. J., 3(4), 507 (1959).

11. T. Romaškevič, E. Viskantienė, S. Budrienè, A. Ramanavičienè, G. Dienys, J. Mol. Catal. B: Enzym., 64(3-4), 172 (2010).

12. G. Socrates, Infrared and Raman Characteristic Group Frequencies, Wiley, New York (2001).
13. C.-C. Lin, C.-T. Chen, U.S. Patent 8293942, Oct. 23, 2012.

14. K. Venkatramanan, V. Arumugam, Int. J. Thermophys., 27, 66 (2006).

15. S. Z. Erhan, S. Asadauskas, A. Adhvaryu, J. Am. Oil Chem. Soc., 79(11), 1157 (2002).

16. S. J. Asadauskas, A. Grigucevičienè, K. Leinartas, D. Bražinskienè, Tribol. Int., 44(5), 557 (2011).

17. A. Stončius, I. Liaščukienè, S. Jankauskas, S. Asadauskas, Ind. Lubr. Tribol., 65(3), 209 (2013).

18. M. Myhre, S. Saiwari, W. Dierkes, J. Noordermeer, Rubber Chem. Technol., 85, 408 (2012).

19. I. Liaščukienė, M. Steffenhagen, S. Asadauskas, J.-F. Lambert, J. Landoulsi, Langmuir, 30(20), 5797 (2014).

20. J. Shi, K. Jiang, D. Ren, et al., J. Appl. Polym. Sci., 129, 999 (2012).

Antanas Strakšys, Ignas Valsiūnas, Giedrius Stalnionis, Olegas Eicher-Lorka, Zenonas Kuodis, Dalia Bražinskienė, Artūras Jukna, Svajus Asadauskas

\section{POLIURETANINIŲ KLIJŲ POVEIKIS SMULKINTOS GUMOS KOMPOZITŲ TEMPIMO IR GNIUŽDYMO SAVYBE்MS}

Santrauka

Guma iš eksploatuoti nebetinkamų padangų dažnai naudojama kaip antrinè žaliava kompozitinių medžiagų gamybai. Tokiose receptūrose plačiai naudojami poliuretano klijai, kadangi jie efektyviai suriša gumos daleles. Šiame darbe tirtos susmulkintos lengvụjų automobilių padangos ir sunkvežimių padangų protektorių nuorěžos. Tolueno diizocianatas parinktas kaip kietiklis pre-polimerinei dervai polieterio pagrindu. Naudojant skirtingą kietiklio koncentraciją, polimerizacijos trukmę ir temperatūrą, buvo pagamintos kompozitu plokštelès. Skenuojanti elektroninė mikroskopija parodè, kad plokštelių viduje susiformavę ertmès yra skirtingos prigimties, todel labai tikètina, kad klijų koncentracijos, vilgumo ir polimerizacijos režimo įtaka kompozito struktūrai yra itin reikšminga. Kompozitų tempimo ir gniuždymo savybès labiau priklausė nuo klijų kiekio nei nuo polimerizacijos temperatūros pokyčių, esant žemesnei nei $60^{\circ} \mathrm{C}$ temperatūrai. Išsamesnès žinios apie tokių kompozitų fizinių ir mechaninių savybių kontrolę prisidètų siekiant, kad gumos atliekos būtu perdirbamos tikslingai, nekenkiant aplinkai ir visuomenei. 